\title{
Characterisation of Colour Components and Polymeric Pigments of Commercial Red Wines by Using Selected UV-Vis Spectrophotometric Methods
}

\author{
A. Versari ${ }^{*}$, G.P. Parpinello, A.U. Mattioli \\ Dipartimento di Scienze degli Alimenti, Università di Bologna, P.zza Goidanich 60, Cesena 47023, Italy
}

Submitted for publication: November 2006

Accepted for publication: February 2007

Key words: co-pigmentation; polymeric pigments; Sangiovese; tannins; wine.

\begin{abstract}
The composition of the colour components of commercial red wines from Italy was analysed in terms of total colour, co-pigmentation, $\mathrm{SO}_{2}$-resistant pigments, small and large polymeric pigments, and tannins. A total of 128 wines, including Sangiovese, Cabernet Sauvignon, Nero d'Avola, Merlot, Marzemino, Negroamaro, Aglianico, Cannonau and Rossese di dolceacqua from five vintages (1999 to 2003) were analysed. The composition of the wines showed significant differences in terms of total colour and co-pigmentation. Total colour at $520 \mathrm{~nm}$ was highest in

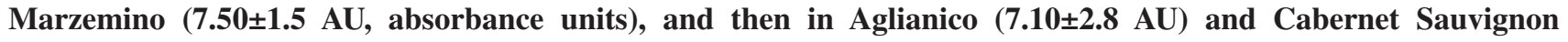
$(5.01 \pm 2.50 \mathrm{AU})$. The level of large and small polymeric pigments in Sangiovese wines showed a range from 0.05 to 0.40 and 0.10 to $0.27 \mathrm{AU} 520 \mathrm{~nm}$ respectively. The variation in the level of polymeric pigments is affected by a number of factors, including vintage, grape composition, fermentation and storage conditions.
\end{abstract}

\section{INTRODUCTION}

The colour components of wine are important parameters that contribute to the sensory characteristics (e.g. colour and astringency) and the antioxidant properties of wine (Kanner et al., 1994; Hagerman et al., 1998; Waterhouse, 2002; López-Vélez et al., 2003). The colour of red wine is the result of an interesting and challenging, complex mixture of several components, including free monomeric anthocyanins (Mazza, 1995), the enhancement of their colour due to co-pigmentation with other noncoloured phenolics (Boulton, 2001), and polymeric pigments (Somers, 1971). The colour of a red wine continues to change throughout its life and can be affected by a number of winemaking practices and environmental conditions. During fermentation, and especially during aging, the monomeric anthocyanins are thought to be gradually incorporated into polymeric pigments and this confers colour stability to a wine (Singleton and Esau, 1969; Somers and Evans, 1974; Ribéreau-Gayon, 1982). The mechanisms, the products and the kinetics of polymer formation in wine are only partially known (Fulcrand et al., 2004; Kennedy and Hayasaka, 2004).

Objective measurement of the components of wine colour is an essential part of the modern concept of winemaking. In this view, the availability of new methods for the measurement of polymeric pigments provides important tools for a better understanding of the chemistry of red wine colour. The spectrophotometric assays developed thus far are based on the assumption that the polymeric pigments are much less sensitive than the anthocyanins to $\mathrm{SO}_{2}$ and to changes in $\mathrm{pH}$. The classic spectrophotometric assay of Ribéreau-Gayon and Stonestreet (1965) measures the polymeric pigments of wine after the bisulphite bleaching of anthocyanin monomers carried out on an acidified sample $(\mathrm{pH}<1)$. Somers and Evans $(1974$; 1977) have developed a set of spectrophotometric measures to determine the amount of total anthocyanins and polymeric pigments in red wines. This procedure is based upon two assumptions: (i) bisulphite bleaches only the monomeric anthocyanins; and (ii) the colour of the polymeric pigments increases by a factor of $5 / 3$ on acidification. Bakker et al. (1986) have shown that oligomeric pigments are also bleached to some extent by bisulphite.

Recently, Harbertson et al. (2003) proposed a new method for the analysis of the polymeric pigments in wine based on a combination of protein precipitation and the bleaching effect of bisulphite. This method allows for the quantification of two classes of non-bleachable polymeric pigments: small polymeric pigments (SPP) that are not precipitable with protein, and large polymeric pigments (LPP), which are precipitable with protein. The SPP fraction probably contains several anthocyanin-derived compounds in various proportions that have been formed through different mechanisms, such as cross-linking reaction, direct reaction and cyclo-addition. The LPP fraction would be expected to contain anthocyanins that have reacted directly with polymeric flavan-3-ols or polymeric pigments that have been formed by acetaldehyde cross-linking. The levels of SPP and LPP have been monitored in grape berries, and information on their content in commercial wines is limited to Zinfandel, Pinot noir, Cabernet Sauvignon and Syrah (Adams et al., 2004).

The aim of this study was to characterise selected colour components, including co-pigmentation, small and large polymeric pigments and tannins, of a variety of commercial red wines from Italy, especially from Sangiovese grapes. 


\section{MATERIALS AND METHODS}

\section{Wine samples}

A total of 128 samples (n) of commercial bottled red wines from nine regions in Italy, including Sangiovese $(\mathrm{n}=70$ samples), Cabernet Sauvignon $(n=13)$, Nero d'Avola $(n=10)$, Merlot $(n=$ 9), Marzemino $(n=7)$, Negroamaro $(n=6)$, Aglianico $(n=5)$, Cannonau $(n=4)$, and Rossese di dolceacqua $(n=4)$, were analysed (see Table 1). The map in Figure 1 shows the regions of origin of the red wines analysed in this study. The wines were analysed at between three and 48 months of age (vintage years: 1999 to 2003).

\section{Spectrophotometric method of Boulton}

For each wine (128 samples), the following parameters were measured by spectrophotometric assay according to the literature: total colour, co-pigmentation and $\mathrm{SO}_{2}$-resistant pigments (Boulton et al., 1999). The samples were filtered through a 0.45 $\mu \mathrm{m}$ polytetrafluoroethylene membrane (PTFE) syringe filter and the wine $\mathrm{pH}$ was adjusted to 3.60, before spectrophotometric analysis was done using a Shimadzu 1240 model (Shimadzu, Milan, Italy). Twenty microlitres of $10 \%(\mathrm{v} / \mathrm{v})$ acetaldehyde was added to $2 \mathrm{~mL}$ of wine and, after $45 \mathrm{~min}$ at room temperature, the total colour of the wine was measured at $520 \mathrm{~nm}$. To another $2 \mathrm{~mL}$ of wine, $160 \mu \mathrm{l}$ of $5 \%(\mathrm{w} / \mathrm{v}) \mathrm{SO}_{2}$ was added, and then the value of the $\mathrm{SO}_{2}$-resistant pigments was measured at $520 \mathrm{~nm}$. For co-pigmentation, the absorbance of wine at $520 \mathrm{~nm}$ was read after a sample dilution of 1:19 in a $12 \%$ ethanol, $\mathrm{pH} 3.60$ potassium bitartrate buffer, corrected for the dilution. There are $\mathrm{pH}$ effects on the free monomeric anthocyanin ionisation, the colour of the co-pigmented form, and the coloured polymers. The selected $\mathrm{pH}$ value (3.60) provides the only rational basis on which to compare colour components, which are independent of $\mathrm{pH}$ effects across all wines.

\section{Spectrophotometric method of Adams}

A set of 40 Sangiovese wines from the Emilia-Romagna region was further analysed by spectrophotometric methods as described in the literature for the following parameters: small and large polymeric pigments (Harbertson et al., 2003), and tannin (Harbertson et al., 2002).

Simultaneous analysis of the polymeric pigments and tannin in wines required two $1.5 \mathrm{~mL}$ microfuge tubes for each sample. The first tube was made up by dispensing $1 \mathrm{~mL}$ of the acetic acid/

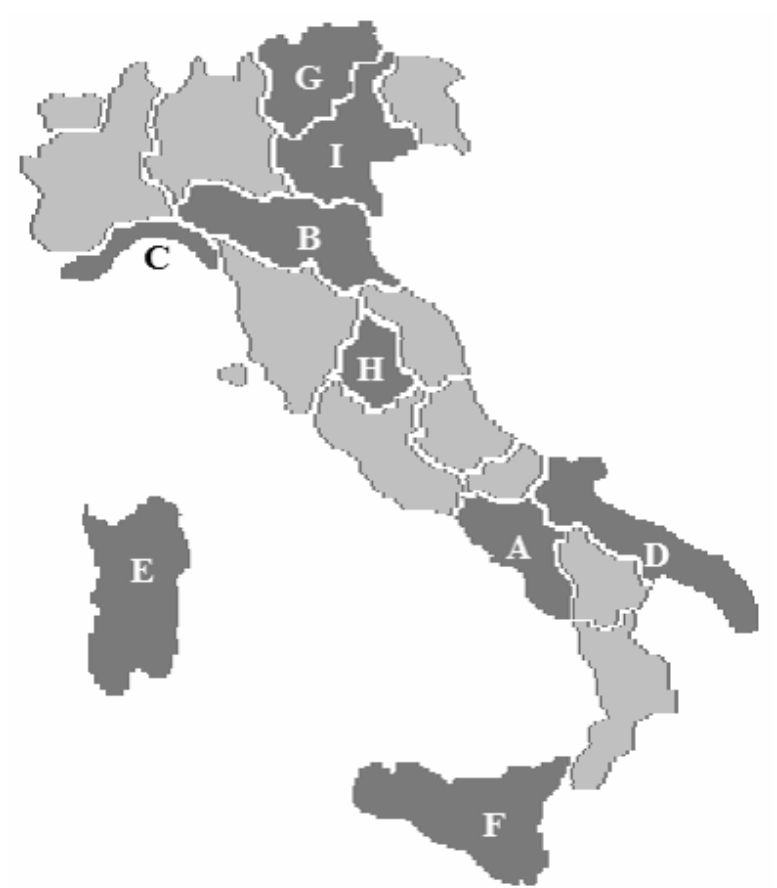

FIGURE 1

Map of Italy showing the origin of the red wines analysed in this study. Regions: (A) Campania; (B) Emilia-Romagna; (C) Liguria; (D) Puglia; (E) Sardegna; (F) Sicilia; (G) Trentino; (H) Umbria; (I) Veneto.

$\mathrm{NaCl}$ buffer (containing $200 \mathrm{mM}$ acetic acid and $170 \mathrm{mM} \mathrm{NaCl}$ adjusted to $\mathrm{pH} 4.9$ with $\mathrm{NaOH}$ ) into the tube and then adding 500 $\mu \mathrm{L}$ of the diluted wine (with a buffer of $12 \%$ aqueous ethanol (v/v), containing $5 \mathrm{~g} / \mathrm{L}$ potassium bitartrate adjusted to $\mathrm{pH} 3.3$ with $\mathrm{HCl}$ ). One $\mathrm{mL}$ of the mixture was transferred to a cuvette and the absorbance at $520 \mathrm{~nm}$ was determined (reading $A$ ). Then $80 \mu \mathrm{L}$ of $0.36 \mathrm{M}$ potassium metabisulphite was added and mixed, and the absorbance at $520 \mathrm{~nm}$ was redetermined after a $10 \mathrm{~min}$ incubation (reading $B$ ). For the second tube, $1 \mathrm{~mL}$ of the acetic acid/NaCl buffer containing bovine serum albumin at $1 \mathrm{mg} / \mathrm{mL}$ (BSA Fraction V powder, Sigma, Milan, Italy) was put into a 1.5 $\mathrm{mL}$ microfuge tube, and $500 \mu \mathrm{L}$ of the diluted wine was added. The mixture was allowed to incubate at room temperature for 15 min with slow agitation. After incubation, the sample was cen-

\section{TABLE 1}

Origin, type and number of red wines from the different regions of Italy.

\begin{tabular}{lll}
\hline Code & Region & Wine (number of samples) \\
\hline A & Campania: & Aglianico (5) \\
B & Emilia-Romagna: & Merlot (2), Sangiovese (68), Cabernet Sauvignon (11) \\
C & Liguria: & Rossese di dolceacqua (4) \\
D & Puglia: & Sangiovese (2), Negroamaro (6) \\
E & Sardegna: & Cannonau (4) \\
F & Sicilia: & Merlot (2), Nero d'Avola (10) \\
G & Trentino: & Merlot (1), Marzemino (7) \\
H & Umbria: & Merlot (1) \\
I & Veneto: & Merlot (3), Cabernet Sauvignon (2) \\
\hline
\end{tabular}


trifuged for $5 \mathrm{~min}$ at $13500 \mathrm{~g}$ to pellet the tannin-protein precipitate. One millilitre of the supernatant was put into a cuvette, 80 $\mu \mathrm{L}$ of $0.36 \mathrm{M}$ potassium metabisulphite was added and, after a 10 min incubation, the absorbance was determined at $520 \mathrm{~nm}$ (reading $C$ ). The absorbance due to MP, SPP and LPP is given as (AB), C and (B-C) respectively.

The absorbance due to polymeric pigments in the protein-tannin precipitate was determined by redissolving the tannin-protein precipitate (from the second tube above) and measuring the absorbance at $510 \mathrm{~nm}$. The tannin-protein pellet from tube two was first washed with $250 \mu \mathrm{L}$ of the acetic acid/ $\mathrm{NaCl}$ buffer, and the sample was recentrifuged for $1 \mathrm{~min}$ at $13500 \mathrm{~g}$. The wash solution was discarded, after which $875 \mu \mathrm{L}$ of a buffer containing $5 \%$ triethanolamine (TEA) (v/v) and 5\% sodium dodecyl sulphate (SDS; lauryl sulphate, sodium salt, Sigma, Milan, Italy) (w/v) was added. After incubation for $10 \mathrm{~min}$ at room temperature, the tube was vortexed and the absorbance at $510 \mathrm{~nm}$ was determined. This absorbance represents the amount of polymeric pigments that precipitated with the protein. For tannin analysis, $125 \mu \mathrm{L}$ of the ferric chloride hexahydrate (Sigma, Milan, Italy), was added and the absorbance at $510 \mathrm{~nm}$ was determined after a $10 \mathrm{~min}$ incubation. The absorbance due to tannins in the sample is calculated as the final absorbance minus the background (absorbance value due to the reagents without the sample) and expressed in catechin equivalents by comparison with a standard curve pre- pared with standard solution of (+)-catechin (Extrasynthese, Genay, France), using eight concentration levels ranging from 50 to $500 \mathrm{mg} / \mathrm{L}\left(R^{2}=0.999\right)$. All data are expressed in absorbance units (AU) with $1 \mathrm{~cm}$ length path and corrected by dilutions, unless otherwise specified.

\section{Statistical analysis}

The statistical analysis of the data, including linear regression analysis, analysis of variance (ANOVA) and post-hoc comparison by Tukey HSD test for unequal sample size at 5\% probability level ( $\mathrm{p} \leq 0.05$ ), was performed using Statistica 5.1 (StatSoft, Tulsa, OK).

\section{RESULTS AND DISCUSSION}

This investigation was initiated as a survey of Sangiovese wines because of the economic importance of this grape cultivar in the Emilia-Romagna region. Taking into account the scientific and practical interest in the analysis of the colour components of red wine and the availability of additional wines, it was decided to include wines from two international varieties in this study, viz. Cabernet Sauvignon and Merlot, as well as wines from local emerging grape varieties, such as Cannonau, Marzemino and Nero d'Avola.

The first step in the study focused on the analyses of total colour, co-pigmentation, and $\mathrm{SO}_{2}$-resistant pigments in the wines using Boulton's method. The composition of the wines showed a

TABLE 2

Composition and statistical analysis of 128 red wines from Italy. All parameters are expressed as AU at $520 \mathrm{~nm}$.

\begin{tabular}{|c|c|c|c|c|}
\hline \multirow{2}{*}{ Wine } & \multirow{2}{*}{ N. sample } & Total color & Copigmentation & $\mathrm{SO}_{2}$ resistant pigments \\
\hline & & Mean \pm SD* & Mean \pm SD* & Mean \pm SD $* *$ \\
\hline Sangiovese & 70 & $4.17 \pm 1.31 \mathrm{a}$ & $0.35 \pm 0.38 \mathrm{a}$ & $2.36 \pm 1.00$ \\
\hline Cabernet Sauvignon & 3 & $5.01 \pm 2.50 \mathrm{ab}$ & $0.41 \pm 0.42 \mathrm{a}$ & $3.25 \pm 2.16$ \\
\hline Cannonau & 4 & $3.71 \pm 0.87 \mathrm{a}$ & $0.71 \pm 0.64 \mathrm{ab}$ & $1.65 \pm 0.76$ \\
\hline Merlot & 9 & $4.70 \pm 1.63 \mathrm{a}$ & $0.60 \pm 0.37 \mathrm{ab}$ & $2.09 \pm 0.99$ \\
\hline Aglianico & 5 & $7.10 \pm 2.90 \mathrm{~b}$ & $0.39 \pm 0.30 \mathrm{ab}$ & $3.03 \pm 0.86$ \\
\hline Negroamaro & 6 & $4.51 \pm 1.19 \mathrm{a}$ & $0.80 \pm 0.53 \mathrm{ab}$ & $2.29 \pm 0.78$ \\
\hline Marzemino & 7 & $7.50 \pm 1.50 \mathrm{~b}$ & $1.18 \pm 0.63 b$ & $1.91 \pm 0.40$ \\
\hline Nero d'Avola & 10 & $3.68 \pm 1.18 \mathrm{a}$ & $0.32 \pm 0.30 \mathrm{a}$ & $1.85 \pm 0.57$ \\
\hline Rossese & 4 & $2.48 \pm 0.34 \mathrm{a}$ & $0.62 \pm 0.66 \mathrm{ab}$ & $0.86 \pm 0.32$ \\
\hline
\end{tabular}

*Group comparisons by means of Tukey HSD test for unequal sample size. Means within each column with changed letter are significantly different using Tukey HSD test $(\mathrm{P} \leq 0.05)$.

$* *$ Non-significant difference at $\mathrm{p}-$ level $\leq 0.05$.

\section{TABLE 3}

Composition of 40 Sangiovese wines from Emilia-Romagna region, Italy.

\begin{tabular}{|c|c|c|c|c|c|c|}
\hline \multirow[b]{3}{*}{ Year } & \multirow[b]{3}{*}{ No samples } & LPP & SPP & $\mathbf{L P P}+\mathbf{S P P}$ & LPP/SPP & Tannins \\
\hline & & AU 520 nm & AU $520 \mathrm{~nm}$ & AU 520 nm & - & $\mathrm{g} / \mathrm{l}$ \\
\hline & & mean \pm SD & mean \pm SD & mean \pm SD & mean \pm SD & mean \pm SD \\
\hline 2003 & 1 & 0.33 & 0.71 & 1.04 & 0.46 & 0.23 \\
\hline 2002 & 14 & $1.09 \pm 0.37$ & $0.99 \pm 0.33$ & $2.08 \pm 0.61$ & $1.17 \pm 0.43$ & $0.49 \pm 0.19$ \\
\hline 2001 & 14 & $1.21 \pm 0.35$ & $1.15 \pm 0.32$ & $2.35 \pm 0.35$ & $1.13 \pm 0.38$ & $0.67 \pm 0.29$ \\
\hline 2000 & 8 & $1.64 \pm 0.41$ & $1.18 \pm 0.38$ & $2.82 \pm 0.57$ & $1.56 \pm 0.69$ & $0.88 \pm 0.44$ \\
\hline 1999 & 3 & $1.35 \pm 0.23$ & $1.11 \pm 0.24$ & $2.46 \pm 0.35$ & $1.25 \pm 0.37$ & $0.82 \pm 0.04$ \\
\hline
\end{tabular}


significant difference in terms of total colour and co-pigmentation, while there was no significant difference between the wines regarding $\mathrm{SO}_{2}$-resistant pigments (see Table 2). Marzemino and Aglianico showed the greatest total colour at $520 \mathrm{~nm}$, followed by Cabernet Sauvignon, and then the others wines. The level of copigmentation was highest in Marzemino wines, and lowest in Sangiovese. The highest content of $\mathrm{SO}_{2}$-resistant pigments was found in Cabernet Sauvignon (3.25 \pm 2.16 AU $520 \mathrm{~nm}$ ), whereas Sangiovese wines showed an intermediate level of $\mathrm{SO}_{2}$-resistant pigments $(2.36 \pm 1.00 \mathrm{AU} 520 \mathrm{~nm})$. In terms of colour, Marzeminio and Aglianico wines seem to be suitable for aging due to the high level of their total colour and $\mathrm{SO}_{2}$-resistant pigments.

The general levels of $\mathrm{SO}_{2}$-resistant pigments found in the analysed wines are comparable with the values reported in other papers concerning studies of polymeric pigments in different wines from Canada (Mazza et al., 1999), Italy (Piergiovanni et al., 1986; Boselli et al., 2004), Spain (Gomez-Plaza, et al., 1999), the USA (Nagel and Wulf, 1979), and Australia (Somers and Evans, 1974).

It is well documented in the literature that the grape cultivar affects the amount of total colour and the co-pigmentation of wine to a large extent (Boulton et al., 1999; Mazza et al., 1999; Boselli et al., 2004; Versari et al., 2004). The data presented here support this view. The co-pigmentation of anthocyanins in wines is a competitive equilibrium involving several anthocyanins and many cofactors. Wines made from grapes high in cofactors and/or with a prevalence of acylated forms of the non-malvidin pigments in their anthocyanin pattern may have a higher level of co-pigmentation (Boulton, 2001). This is partly the reason for poorer co-pigmentation in the Sangiovese wines, which lack the acylated pigments (Baldi and Romani, 1992), whereas Merlot and Cabernet Sauvignon wines contain high levels of acylated anthocyanins (Mattivi et al., 1995), followed by Aglianico (Calò et al., 1994) and Cannonau (Castia et al., 1992). Furthermore, co-pig-

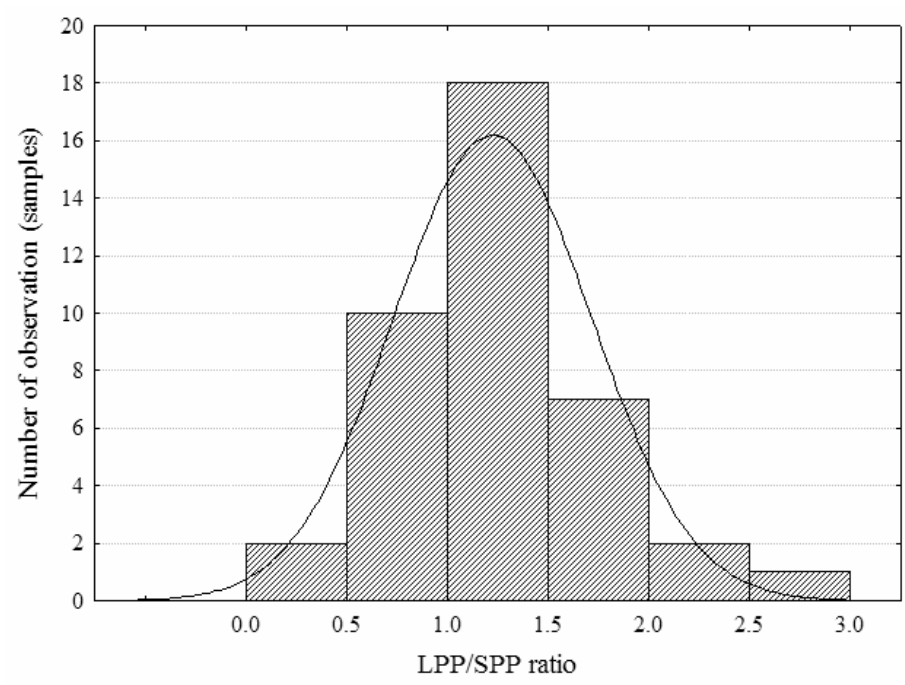

FIGURE 2

Frequency distribution of LPP/SPP ratio found in 40 Sangiovese wines from the Emilia-Romagna region (Italy). mentation is typical of young wines, which can explain up to $50 \%$ of the total colour (Boulton, 2001).

To obtain more insight into the composition of Sangiovese wines in terms of colour components, the $\mathrm{SO}_{2}$-resistant pigments were analysed using a more selective method proposed by Harbertson et al. (2003), which allows the measurement of two groups of polymeric pigments: SPP and LPP. This part of the investigation was conducted on a set of 40 Sangiovese wines that were between three and 48 months old (vintage years: 1999 to 2003) at the time of these analyses. The $\mathrm{SO}_{2}$-resistant pigments accounted for the average percentage of $62 \%, 72 \%, 65 \%$ and $54 \%$ of the total colour of four-year-old (1999), three-year-old (2000), two-year-old (2001) and one-year-old (2002) Sangiovese wines respectively. Table 3 shows the level of LPP, SPP and tannins in Sangiovese wines. The comparison between vintages showed an increasing level of LPP, SPP and tannins in Sangiovese wines during the first three years, i.e. 2003 to 2000. The variation in the level of polymeric pigments is affected by a number of factors, including vintage, grape composition, fermentation and storage conditions. In particular, the decrease in polymeric pigments may be due to precipitation and/or the lighter hue of the larger polymers. There is general consensus on the increase in LPP content in red wines with age (De Beer et al., 2004).

The levels of LPP (range 0.3 to $2.3 \mathrm{AU}$ ) and SPP (range 0.6 to 2.0 AU) found in Sangiovese wines are generally higher than the values reported for wines made from local red grape varieties in the Marche region, Italy (Boselli et al., 2004), and for red wines from the USA (De Beer et al., 2004). The distribution of the LPP/SPP ratio in Sangiovese wines covered a range of 0.15 to 2.78 (see Figure 2), and was in agreement with the values reported on Pinot Noir (range 0.14 to 2.20), Cabernet Sauvignon (0.18 to 3.93), and Syrah (0.28 to 1.71) (Harbertson et al., 2003).

The highest correlation value was found between the determination of $\mathrm{SO}_{2}$-resistant pigments by Boulton's assay at $\mathrm{pH} 3.6$ and the sum of LPP and SPP as determined by Adams' assay using

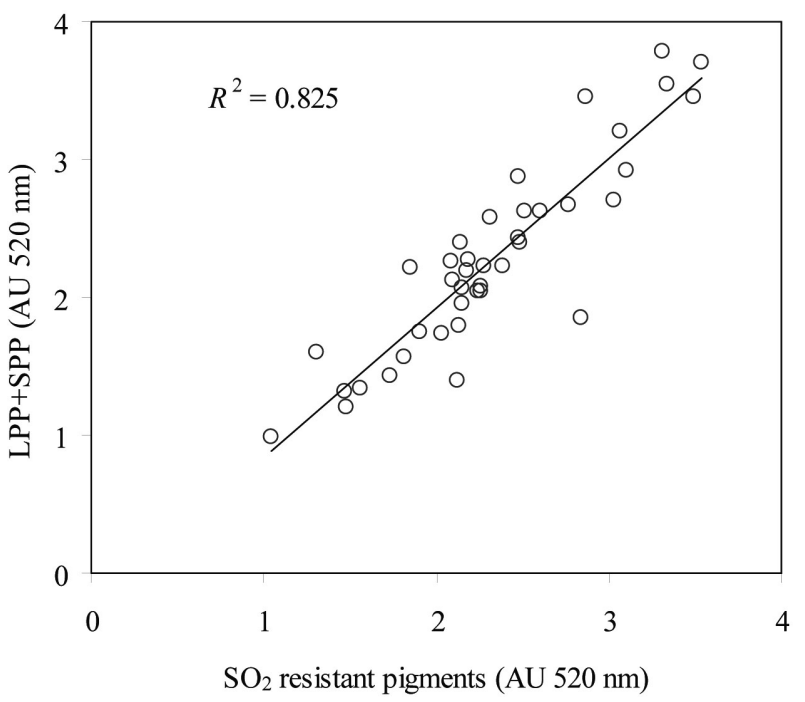

FIGURE 3

Correlation between the amount of $\mathrm{SO}_{2}$-resistant pigments determined by Boulton's assay and LPP+SPP determined by Adams's assay found in 40 Sangiovese wines from the Emilia-Romagna region (Italy). 
combined protein precipitation and bisulphate bleaching at $\mathrm{pH}$ $4.9\left(r=0.91 ; R^{2}=0.825\right)$ (see Figure 3 ). This finding confirms that Adams's assay fractionates polymeric pigments into two classes, those that precipitate with protein and those that do not (Harbertson et al., 2003).

\section{CONCLUSIONS}

In conclusion, the recent availability of selective UV-Vis methods for the measurement of parameters that have not been taken into account in traditional wine colour measurements represents a valuable opportunity for researchers and winemakers. The choice of a proper analytical method is critical, thought in many cases the results that are obtained differ on the basis of the analytical procedure.

\section{LITERATURE CITED}

Adams, D.O., Harbertson, J.F. \& Picciotto, E.A., 2004. Fractionation of red wine polymeric pigments by protein precipitation and bisulphite bleaching. In: Waterhouse, A.L. \& Kennedy, J.A. (eds). Red Wine Color: Revealing the Mysteries. American Chemical Society 886, Washington, DC. pp. 275 - 287.

Bakker, J., Preston, N.W. \& Timberlake, C.F., 1986. The determination of anthocyanins in aging red wines: Comparison of HPLC and spectral methods. Am. J. Enol. Vitic. 37, 121-126.

Baldi, A. \& Romani, A., 1992. Studio su alcuni composti polifenolici in uve, mosti, vini della Toscana. Enotecnico 6, 105-119.

Boselli, E., Boulton, R.B., Thorngate, J.H. \& Frega, N.G., 2004. Chemical and sensory characterization of DOC wines from Marche (Italy) related to vintage and grape cultivars. J. Agric. Food Chem. 52, 3843-3854.

Boulton, R., Neri, R., Levengood, J. \& Vaadia, M., 1999. Copigmentation of anthocyanins in Cabernet Sauvignon and Merlot wines from the Napa valley of California. In: Lonvaud-Funel, A. (ed). Proc. 6th Symposium International d'Enologie, Tec. \& Doc. Publ., Paris, France. pp. 35 - 38.

Boulton, R., 2001. The copigmentation of anthocyanins and its role in the color of red wine: A critical review. Am. J. Enol. Vitic. 52, 67-87.

Calò, A., Tomasi, D., Cravero, M.C. \& Di Stefano, R., 1994. Contributo alla caratterizzazione e classificazione varietale (Vitis sp.) attraverso la determinazione degli antociani e degli acidi idrossicinnamoiltartarici della buccia di varietà a bacca rossa. Rivista Vitic. Enol. (Italy) 3, 13-26.

Castia, T., Franco, M.A., Mattivi, F., Muggiolu, G., Sferlazzo, G. \& Versini, G., 1992. Characterization of grapes cultivated in Sardinia: chemometric methods applied to the anthocyanic fraction. Sci. Aliment. 12, 239-255.

De Beer, D., Harbertson, J.F., Kilmartin, P.A., Roginsky, V., Barsukova, T., Adams, D. O. \& Waterhouse, A.L., 2004. Phenolics: A comparison of diverse analytical methods. Am. J. Enol. Vitic. 55, 389-400.

Fulcrand, H., Atanasova, V., Salas, E. \& Cheynier, V., 2004. The fate of anthocyanins in wine: Are there determining factors? In: Waterhouse, A.L. \& Kennedy, J.A. (eds). Red Wine Color: Revealing the Mysteries. American Chemical Society 886, Washington, DC. pp. $68-88$.

Gomez-Plaza, E., Gil-Munoz, R., Lopez-Roca, J.M. \& Martinez, A., 1999. Color and phenolic compounds of a young red wine as discriminating variables of its aging status. Food Res. Int. 32, 503-507.
Hagerman, A.E., Riedl, K.M., Jones, G.A., Sovik, K.N., Ritchard, N.T., Hartzfeld, P.W. \& Riechel, T.L., 1998. High molecular weight plant polyphenolics (tannins) as biological antioxidants. J. Agric. Food Chem. 46, 1887-1892.

Habertson, J.F., Kennedy, J.A., 2002. Tannin in skins and seeds of Cabernet Sauvignon, Shiraz and Pinot Noir berries during ripening. Am. J. Enol. Vitic. 53, 54-59.

Harbertson, J.F., Picciotto, E.A. \& Adams, D.O., 2003. Measurement of polymeric pigments in grape berry extracts and wine using a protein precipitation assay combined with bisulfite bleaching. Am. J. Enol. Vitic. 54, 301-306.

Kanner, J., Frankel, E.N., Granit, R., German, B. \& Kinsella, J.E., 1994. Natural antioxidants in grapes and wines. J. Agric. Food Chem. 42, 64-69.

Kennedy, J.A. \& Hayasaka, Y., 2004. Compositional investigation of pigmented tannin. In: Waterhouse, A.L. \& Kennedy, J.A. (eds). Red Wine Color: Revealing the Mysteries. American Chemical Society 886, Washington, DC. pp. 247 - 264.

López-Vélez, M., Martínez-Martínez, F. \& Del Valle-Ribes, C., 2003. The study of phenolic compounds as natural antioxidants in wine. Crit. Rev. Food Sci. Nutr. 43, 233-244.

Mattivi, F., Monetti, A. \& Nicolini, G., 1995. Composizione fenolica e caratterizzazione di vini rossi monovarietali. Enotecnico (Italy) 6, 69-79.

Mazza, G., 1995. Anthocyanins in grapes and grape products. Crit. Rev. Food Sci. Nutr. 35, 341-371.

Mazza, G., Fukumoto, L., Delaquis, P., Girare, P. \& Ewert, B., 1999. Anthocyanins, phenolics, and color of Cabernet Franc, Merlot, and Pinot Noir wines from British Columbia. J. Agric. Food Chem. 47, 4009-4017.

Nagel, C.W. \& Wulf, L.W., 1979. Changes in the anthocyanins, flavonoids, and hydroxycinnamic acid esters during fermentation and aging of Merlot and Cabernet Sauvignon. Am. J. Enol. Vitic. 30, 111-116.

Piergiovanni, L., Volontario, G. \& Scibona A., 1986. Studio della frazione antocianica: modificazioni nel corso dell'invecchiamento di un vino Barbera. Ind. Bevande (Italy) 6, 202-209, 217.

Ribéreau-Gayon, P. 1982. The chemistry of red wine color. In: Webb, A.D. (ed). The Chemistry of Winemaking. American Chemical Society, Advanced Chemistry Series, N. 137, Washington, DC. pp. $50-87$.

Ribéreau-Gayon, P. \& Stonestreet, E., 1965. Le dosage des anthocyanes dans le vin rouge. Bull. Soc. Chim. Fr. 9, 2649-2652.

Singleton, V.L. \& Esau, P., 1969. Phenolic Substances in Grape and Wines and Their Significance. Academic Press, New York, NY.

Somers, T.C., 1971. The polymeric nature of wine pigments. Phytochemistry 10, 2175-2186.

Somers, T.C. \& Evans, M.E., 1974. Wine quality: Correlations with colour density and anthocyanin equilibria in a group of young red wines. J. Sci. Food Agric. $25,1369-1379$

Somers, T.C. \& Evans, M.E., 1977. Spectral evaluation of young red wines: Anthocyanin equilibria, total phenolics, free and molecular $\mathrm{SO}_{2}$, "chemical age". J. Sci. Food Agric. 28, 279-287.

Versari, A., Boulton, R. \& Thorngate, J., 2004. The prediction of color components of red wines using FTIR, wine analyses, and the method of partial least squares. In: Waterhouse, A.L. \& Kennedy, J.A. (eds). Red Wine Color: Revealing the Mysteries. American Chemical Society 886, Washington, DC. pp. 53 - 67.

Waterhouse, A.L., 2002. The phenolic wine antioxidants. In: Cadenas, E. \& Packer, L. (eds). Handbook of Antioxidants. Marcel Dekker, New York. pp. 401 416. 